\title{
KORZYŚCI ZEWNĘTRZNE PROWADZENIA ZRÓWNOWAŻONYCH WINNIC W POLSCE W WARUNKACH ZMIAN KLIMATU ${ }^{1}$
}

\author{
Mariusz Maciejczak \\ Katedra Ekonomiki i Organizacji Przedsiębiorstw, Wydział Nauk Ekonomicznych \\ Szkoła Główna Gospodarstwa Wiejskiego w Warszawie \\ Kierownik: prof. dr hab. Henryk Runowski
}

Słowa kluczowe: korzyści zewnętrzne, zrównoważona produkcja, winnice, zmiany klimatu Key words: external benefits, sustainable production, vineyards, climate change

JELcode: Q01, Q15

S y n o p s i s. Głównymi celami badań było określenie rodzajów korzyści zewnętrznych związanych z prowadzeniem winnicy zgodnie z zasadami zrównoważonej produkcji, a następnie, w oparciu o wnioski z oceny rozwoju upraw winiarskich w Polsce w warunkach zmian klimatu, zbadanie opinii konsumentów na temat ich warunkowej skłonności do zapłaty wyższej ceny za wino pochodzące z upraw generujących pozytywne efekty zewnętrzne. Stwierdzono, że uprawa winorośli odbywająca się w sposób zrównoważony cechuje się występowaniem korzyści zewnętrznych. Korzyści te wynikają z lokalnego charakteru dóbr publicznych, do których można zaliczyć przede wszystkim dany ekosystem, określany jako terroir i powiązane z nim sieciowo elementy takie jak bioróżnorodność czy krajobraz. Oddziałują one w sposób synergiczny na inne korzyści zewnętrzne o charakterze społecznym, takie jak atrakcyjność turystyczna czy dziedzictwo kulturowe. Wykazano, że uprawa winorośli z przeznaczeniem na wino i produkcja wina w Polsce dynamicznie wzrastają, a zmiany klimatu będą wpływały na dalsze potencjalne możliwości rozwoju tego sektora. Badani konsumenci wskazali, że ważne są dla nich takie atrybuty wina jak ekologiczny sposób produkcji czy praktyki odpowiadające na zmiany klimatu. W większości deklarowali oni gotowość zapłaty za nie więcej niż za cechy związane $\mathrm{z}$ innymi korzyściami zewnętrznymi, takimi jak bioróżnorodność czy krajobraz. Ukierunkowanie polskich winnic na produkcję generującą korzyści zewnętrzne, np. ekologiczną, pozwoli na skorzystanie z efektu sieciowego, co może przełożyć się na chęć konsumentów do zapłaty wyższej ceny za wino.

\section{WSTĘP}

Wraz ze zmianą klimatu, w różnych rejonach świata, pojawiają się zarówno korzystne jak i niekorzystne warunki do prowadzenia określonej produkcji rolnej. Kluczowymi czynnikami o charakterze klimatycznym mającymi wpływ na dokonujące się zmiany są

\footnotetext{
${ }^{1}$ Opracowanie powstało w ramach projektu VITISMART finansowanego przez Narodowe Centrum Badań i Rozwoju w ramach programu ERA-NET CO-FUND FACCE SURPLUS.
} 
w szczególności kwestie związane z dostępnością wody, wysokością temperatur, a także występowaniem ekstremalnych zjawisk pogodowych, takich jak przymrozki czy gradobicia. Zmianom tym towarzyszą pośrednie efekty związane m.in. z inwazją patogenów roślin [Zhenmin, Espinosa 2019]. Jak podkreślono w raporcie Narodowej Akademii Nauk USA jedną z najbardziej wrażliwych na zmiany klimatu roślin jest winorośl. Fakt ten sprawia, że gospodarstwa uprawiające winorośl stają się ważnym wyznacznikiem tempa i skali zmian w ekosystemach produkcyjnych w warunkach zmian klimatu [Lee i in. 2013]. Tym samym można przyjąć, że sam sektor winiarski dostosowujący się do nowych warunków produkcyjnych staje się jednym z wyznaczników wpływu zmian klimatycznych na rynek żywnościowy. Przyjmując perspektywę rynkową warto dodatkowo zauważyć, że dostosowania sektora winiarskiego warunkowane są także zmianami w postawach konsumentów. Już dziś konsumenci zwracają uwagę na sposób uprawy i produkcji oraz ich oddziaływanie na środowisko podczas zakupów wina [Vecchio 2013]. Jednocześnie jak wykazały liczne badania w perspektywie średniookresowej czynniki o charakterze ekologicznym mogą stać się jednymi z dominujących w zakresie preferencji zakupowych wina [Penco 2016, Santini i in. 2015, Klohr i in. 2014, Doods i in. 2013]. Rosnąca świadomość ekologiczna konsumentów wina rzutuje także na ich percepcje w zakresie efektów zewnętrznych, które powstają zarówno podczas uprawy winorośli, jak i produkcji samego wina [Marshall i in. 2010].

W związku ze zmianami klimatycznymi Polska może stać się krajem, w którym uprawy winorośli i produkcja wina gronowego będą miały sprzyjające warunki [Maciejczak, Mikiciuk 2019], a także biorąc pod uwagę, że polscy konsumenci wina poszukują $\mathrm{z}$ tendencją wzrostową win w segmencie premium, gdzie jednym $\mathrm{z}$ wyznaczników jest ekologiczne pochodzenie [KPMG 2014], ważną kwestią staje się określenie korzyści zewnętrznych generowanych przez winnice w Polsce, w szczególności te prowadzone zgodnie ze zasadami zrównoważonego rozwoju, a także oszacowanie, ile za te korzyści potencjalnie skłonni są zapłacić konsumenci.

\section{CEL I METODA BADAŃ}

Głównymi celami badań było określenie, na podstawie przeglądu literatury, rodzajów korzyści zewnętrznych związanych z prowadzeniem winnicy zgodnie z zasadami zrównoważonej produkcji, a następnie zbadanie opinii polskich konsumentów na temat ich stosunku do takich upraw i warunkowej skłonności do zapłaty za pozytywne efekty zewnętrzne generowane przez takie winnice. Dodatkowo celem badań było przedstawienie rozwoju upraw winiarskich w Polsce.

Przegląd literatury oparto o krajowe i zagraniczne publikacje naukowe. Badaniami objęto publikacje naukowe indeksowane w bazach danych Web of Science, Scopus, Google Scholar. Rozwój uprawy winorośli i produkcji wina w Polsce opisano przy wykorzystaniu danych wtórnych pochodzących ze statystyki masowej i publikacji naukowych. Badania opinii konsumentów przeprowadzono przy wykorzystaniu kwestionariusza ankiety obejmującego 15 zamkniętych pytań merytorycznych oraz 6 pytań metryczkowych. Kwestionariusz ankiety poddany został wstępnej weryfikacji podczas badań pilotażowych. Badania właściwe przeprowadzono w pierwszej połowie 2018 r. metodą CATI w oparciu o randomizowany dobór próby. W wyniku badania uzyskano 178 odpowiedzi, 
z czego $\mathrm{z}$ uwagi na niekompletność odrzucono 14 ankiet, tym samym do badań włączono 164 ankiety. Wyniki z ankiet posłużyły jako źródło danych dla wybranej metody wyceny dóbr nierynkowych - metody wyceny warunkowej (ang. Contingent Valuation Method). Mariusz Maciejczak i Paweł Grzelak podkreślili, że jest to jedna z metod wyceny dóbr nierynkowych opartych na preferencjach deklarowanych (ang. Stated Preference Methods), a jej popularność wynika z szerokiego spektrum zastosowań, które mogą dotyczyć badania zarówno wartości użytkowej dóbr, jak i pozaużytkowej [Maciejczak, Grzelak 2013]. W badaniach na rynku wina wykorzystywał ją m.in. Riccardo Vecchio [Vecchio 2013]. W metodzie wyceny warunkowej wykorzystano wariant hipotetycznej gotowości do zapłaty (WTP, ang. Willingness To Pay). Metoda polega na uzyskaniu od potencjalnych lub aktualnych użytkowników odpowiedzi na pytanie, ile byliby gotowi zapłacić za określone dobro lub dany poziom usług dostarczanych przez środowisko [Miłaszewski 2009].

\section{KORZYŚCI ZEWNĘTRZNE W ZRÓWNOWAŻONYCH WINNICACH}

Teoria efektów zewnętrznych stanowi jedną podstaw analitycznych dzisiejszego rolnictwa. Związane jest to głównie $\mathrm{z}$ faktem oddziaływania przez sektor rolny na środowisko naturalne będące miejscem prowadzenia produkcji rolnej, a tym samym kształtowania podstawowego elementu dobrobytu człowieka, jakim jest zapewnienie żywności [Maciejczak 2009]. Jak stwierdzili Andrzej Czyżewski i Piotr Kułyk, druga połowa XX wieku przyniosła niezaprzeczalną szczupłość zasobów środowiskowych, zaś pominięcie wartości dóbr nierynkowych w analizie kosztów i korzyści w działaniach inwestycyjnych lub politycznych doprowadziło do obniżenia, zamiast do wzrostu, dobrobytu społecznego [Czyżewski, Kułyk 2013]. Patrząc przez pryzmat dobrobytu należy stwierdzić, że efekty zewnętrzne są skutkiem nieefektywności rynku. Arthur Pigou argumentował, że sam rynek jest nieefektywny z wielu powodów, głównie alokacyjnych i asymetrii informacji, jednak zawsze wynikiem tej nieefektywności jest występowanie zjawiska efektów zewnętrznych [Pigou 1932]. Według Josepha Stiglitza, jeśli dany podmiot podejmuje działania, które wywierają wpływ na sytuację innych podmiotów działających na tym samym rynku, a nie są rekompensowane odpowiednią płatnością w jedną lub drugą stronę mamy do czynienia z efektem zewnętrznym [Stiglitz 2004]. Efekt taki powstaje, kiedy obserwuje się rozbieżności w relacjach między prywatnymi i społecznymi korzyściami lub kosztami [Gołębiewska, Pajewski 2018]. Tym samym można wskazać pozytywne (korzyści) lub negatywne (koszty) efekty zewnętrzne, które w rachunku ekonomicznym wymagają internalizacji [Harasim 2015].

Tomasz Pajewski i Barbara Gołębiewska wskazali, że efekty zewnętrzne w rolnictwie mogą być bardzo zróżnicowane, ponieważ dotyczą przede wszystkim środowiska naturalnego, które samo w sobie jest bardzo zróżnicowane [Pajewski, Gołębiewska 2018]. Jules Pretty z zespołem podkreślili z kolei, że w zakresie efektów zewnętrznych ujawnia się systemowy charakter rolnictwa, które może generować zarówno negatywne, jak i pozytywne, efekty zewnętrzne w relacji ze środowiskiem [Pretty i in. 2001]. Działania takie związane są m.in. z degradacją lub wzbogacaniem gleby w materię organiczną i składniki mineralne, niszczeniem lub rozwojem bioróżnorodności, ograniczaniem lub rozwojem stosunków wodnych. W odniesieniu do pozytywnych efektów zewnętrznych liczni 
badacze [Pajewski, Gołębiewska 2019, Małażewska 2015, Brelik 2011, Cooper 2009] wskazywali także na systemowy charakter rolnictwa wynikający z jego wielofunkcyjności, który ujawnia się poprzez relacje $\mathrm{z}$ otoczeniem społeczno-gospodarczym. Korzyści zewnętrzne mogą wynikać np. z walorów estetycznych krajobrazu i czystości powietrza, które wpływają na rozwój turystyki. Korzyści te mają charakter dóbr publicznych o ograniczonym zasięgu, tzw. lokalnych, ponieważ dotyczą określonego terenu na którym występują [Harasim 2015].

W badaniach sektora winiarskiego najczęściej wskazuje się właśnie na występowanie lokalnych dóbr publicznych w postaci miejscowego ekosystemu, w którym zlokalizowana jest winnica [Lee i in. 2013, Gibbons i in. 2016]. Zdaniem Giovanni Bellettiego i zespołu tzw. terroir, czyli zespół czynników klimatyczno-glebowych odpowiadających za smak i jakość wina, stanowi dobro publiczne, które wykracza nawet poza sferę lokalną i zostaje włączone w tzw. dobro publiczne łańcucha dostaw [Belletti i in. 2015]. Konsumenci chcą pić wino z odpowiednią apelacją, czyli poświadczeniem pochodzenia wina wyprodukowanego w danej lokalizacji. Powszechnie znanym przykładem jest Szampania i jej sztandarowy produkt szampan, który w zależności od miejsca zbioru winogron do jego produkcji, oznaczany jest jako „cru” [Robinson 2006]. Vasco Boatto z zespołem analizując wpływ terroir i apelacji na region Conegliano-Valdobbiadene we Włoszech, znany z produkcji wina musującego Proseco stwierdzili, że wśród konsumentów tego trunku istnieje potencjalna gotowość do zapłaty wyższej ceny za wino z tytułu zachowania unikalnych cech tego regionu, które konstytuują warunki produkcji Proseco [Boatto i in. 2013]. Z badań Klary Winkler z zespołem wynika, że z terroir związane są inne pozytywne efekty zewnętrzne, przykładowo ukształtowanie krajobrazu, które odgrywa istotną rolę w percepcji jakości wina i zachowaniach nabywczych konsumentów w Anglii i Kalifornii [Winkler $\mathrm{i}$ in. 2016]. Dla badanych konsumentów ukształtowanie krajobrazu z winnicami stanowiło nie tylko znaczny walor estetyczny, ale także swego rodzaju dziedzictwo kulturowe, które należy pielęgnować i zachowywać, rolnicy zaś piastują ważną rolę opiekunów tego dziedzictwa. Ekonomiści wskazujący na rolę terroir jako lokalnego dobra publicznego podkreślali jego znaczenie także dla rozwoju różnych form turystyki, w tym enoturystyki. Inni badacze wskazywali, że odpowiedni terroir może mieć również wpływ na zachowanie i rozwój bioróżnorodności [Stefanucci i in. 2018]. Wpływ ten może być jednak dwojaki. Może mieć charakter kosztu zewnętrznego, jeśli produkcja ma charakter intensywny i odbywa się w sposób industrialny [Tee i in. 2007], lub może stanowić korzyść zewnętrzną, gdy prowadzona jest w sposób zrównoważony [Marshall i in. 2010].

Inne podejście do analizy korzyści zewnętrznych w uprawie winorośli prezentowali Eugenio Pomarici z zespołem, V. Boatto z zespołem czy Lina Lourenco-Gomes i Joao Rebelo, którzy zwracali uwagę nie na lokalizację i związane z nią benefity, a na sposoby prowadzenia upraw i związane z nimi dobre praktyki, które niejednokrotnie wdrażane są $\mathrm{w}$ ramach odpowiednich standardów jakości potwierdzanych certyfikatami [Pomarici $\mathrm{i}$ in. 2015, Boatto i in. 2013, Lourenco-Gomes, Rebelo 2006]. W szczególności sposoby uprawy przyjazne środowisku, takie jak w systemie ekologicznym czy biodynamicznym, $z$ jednej strony charakteryzują się pozytywnym oddziaływaniem na wiele elementów środowiska, tj. bioróżnorodność, stosunki wodne, zasobność gleb, obieg materii [Murray $\mathrm{i}$ in. 2005], z drugiej zaś poprzez certyfikację budzą zaufanie wśród konsumentów, których gotowość do zapłaty wzrasta [Osadebamwen 2015] tak, by pozytywnie wpływać na takie praktyki [Sellers-Rubio, Nicolau-Gonzalbez 2016]. 
Należy stwierdzić, że praktyki te bezpośrednio oddziałują na terroir i związane z nim dobra publiczne, co świadczy o systemowym charakterze pozytywnych efektów zewnętrznych w uprawie winorośli. Korzyści te przenikają się, tworząc pozytywne efekty sieciowe o charakterze synergicznym. Dzięki stosownym praktykom agrotechnicznym i systemowemu podejściu do certyfikowanej produkcji zrównoważonej, np. ekologicznej, możliwe jest zachowanie bioróżnorodności, odpowiedniej zasobności gleb z właściwymi stosunkami wodnymi, dzięki czemu powstanie właściwy do uprawy i produkcji wina ekosystem, który wpływa na kulturowe postrzeganie danego terenu, co dalej przekłada się na jego atrakcyjność turystyczną. To za te działania i czynniki, będące korzyściami zewnętrznymi, deklarują gotowość do zapłaty konsumenci przy zakupie butelki wina.

\section{ROZWÓJ UPRAW WINIARSKICH W POLSCE W WARUNKACH ZMIAN KLIMATU}

Jak wykazały badania modelowe, zmiany klimatu będą miały także wpływ na funkcjonowanie sektora rolnego w Polsce. Zdaniem Macieja Sadowskiego okres wegetacyjny w Polsce określany liczbą dni z temperaturą dobową powietrza wyższą od $5^{\circ} \mathrm{C}$ w perspektywie lat 2021-2050 będzie dłuższy w porównaniu do lat 1971-2000 o 16 dni, natomiast w perspektywie lat 2071-2100 o 41 dni [Sadowski 2014]. Prognozowana wyższa temperatura $\mathrm{w}$ sezonie wegetacji roślin znacząco przyśpieszy rozwój roślin. Zmiany warunków termicznych oraz ich wpływ na rośliny uprawne będzie wymagał w pierwszej kolejności dostosowania terminów prac polowych, natomiast $\mathrm{w}$ dalszej perspektywie również dostosowania struktury upraw. Jak wskazała Alina Kunicka-Styczyńska z zespołem, jedną z szans, jaka pojawi się wraz z tymi zmianami, będzie możliwość rozwoju i szerokiej uprawy winorośli i produkcji wina gronowego w Polsce [Kunicka-Styczyńska i in. 2016]. Według Jerzego Liska obecne zmiany klimatyczne sprzyjają rozwojowi polskiego winiarstwa [Lisek 2008]. Średnia roczna temperatura wykazywała tendencję wzrostową (około $0,5^{\circ} \mathrm{C}$ na dekadę), skróciły się okresy przejściowe, wydłużyły się okresy ciepła, a przebieg zimy stał się łagodniejszy. Jak wykazały badania realizowane w ramach projektu VitiSmart oparte na ankietach przeprowadzonych wśród obecnych producentów, zmiany klimatu będą skłaniały rolników uprawiających winorośl na wino w Polsce do podejmowania działań innowacyjnych [Maciejczak 2017].

W klasyfikacji Unii Europejskiej w odniesieniu do uprawy winorośli Polska została zaliczona do najzimniejszego regionu uprawy winorośli i oficjalnie uznawana za kraj produkujący wino, łącznie z Niemcami (z wyjątkiem Badenii), Czechami (z wyjątkiem Moraw), Belgią i Wielką Brytanią. Ze względu na warunki termiczne, na terytorium Polski wydzielono trzy regiony. Region I to zachodni i południowo-zachodni rejon kraju, obejmujący województwa: lubuskie, dolnośląskie, opolskie, śląskie oraz południowe części województwa wielkopolskiego i łódzkiego. Region II - zagrożony mroźnymi zimami, obejmuje południowy i południowo-wschodni rejon kraju, tj. województwa małopolskie, podkarpackie, świętokrzyskie i południowe części województw: lubelskiego i mazowieckiego. Region III obejmuje pozostałe obszary, gdzie uprawa winorośli jest niemożliwa lub bardzo trudna [Maciejczak, Mikiciuk 2019]. Jak zaznaczył Dawid Olewnicki winnice zakładane i rozwijane są nie tylko w województwach, które powszechnie kojarzą się z tego typu uprawami, a więc województwach południowej Polski, lecz coraz 


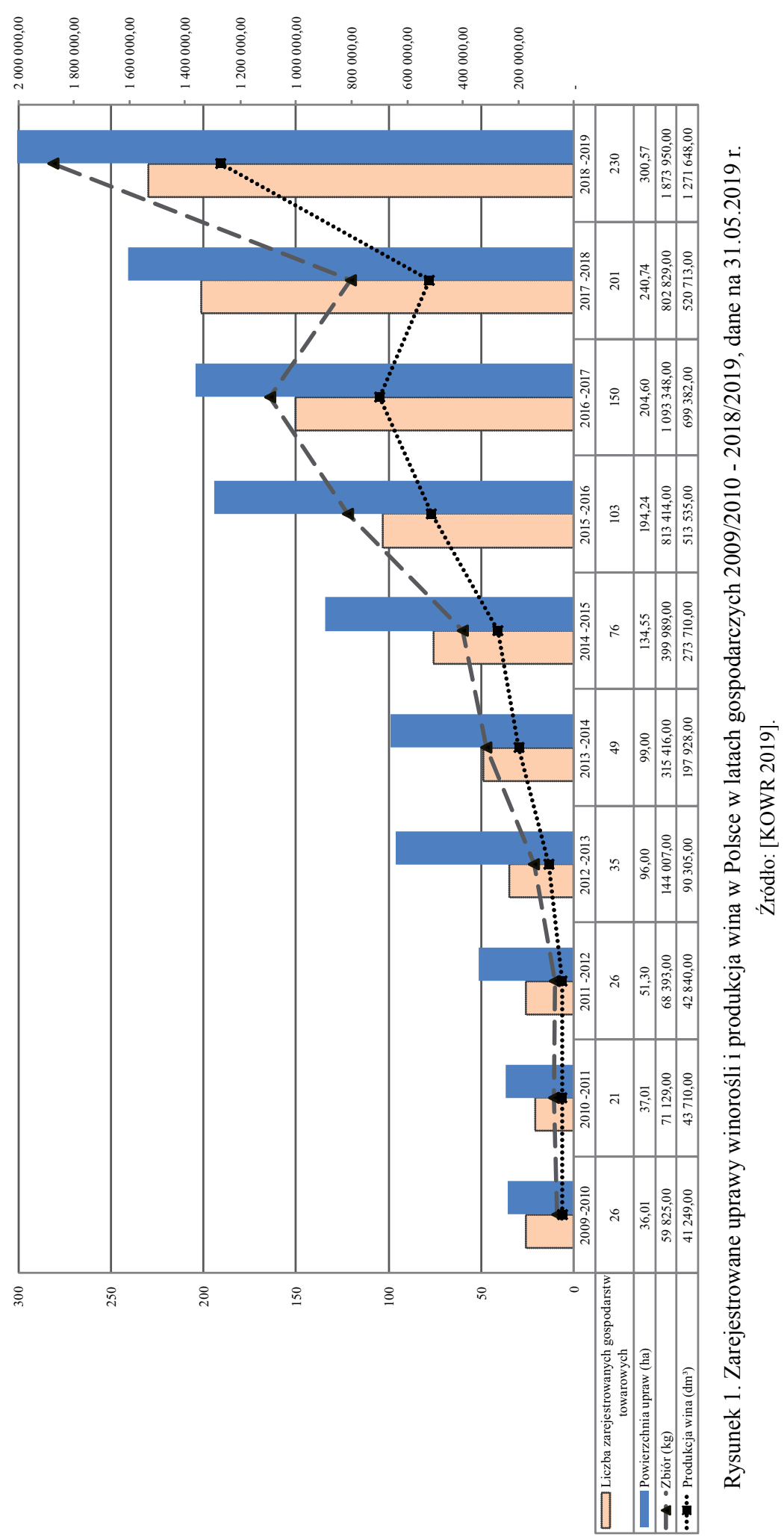


częściej w rejonach Polski centralnej czy północnej, co jest pozytywnym zjawiskiem [Olewnicki 2018].

W 2019 roku w Polsce funkcjonowało około 500 winnic, o szacowanej powierzchni około 700 ha, z czego zarejestrowane jako towarowe było 230 gospodarstw o łącznej powierzchni 395 ha (rysunek 1.). Powierzchnia zarejestrowanych winnic wynosiła od mniej niż 1 ha (około 75\% plantacji) do kilkunastu hektarów [KOWR 2019]. W latach 2009-2018 obserwowano dynamiczny wzrost liczby zarejestrowanych gospodarstw i zarejestrowanej powierzchni winnic w Polsce. W roku 2018 łącznie winiarze zebrali ponad 1,8 tys. ton winogron, zaś produkcja wina wyniosła 12,7 tys. hektolitrów. Ponad $61 \%$ produkcji stanowiły wina białe. D. Olewnicki stwierdził, że zmiany liczby producentów, jak i powierzchni upraw mają charakter wykładniczy, wskutek czego kolejne przyrosty w wartościach bezwzględnych są coraz większe [Olewnicki 2018]. Wskazał ponadto, że brak rejestracji produkcji, zwłaszcza niewielkich, mniej niż hektarowych upraw, wynika ze stosunkowo wysokich kosztów zgłoszenia, zbyt skomplikowanego systemu ewidencjonowania i monitorowania produkcji.

\section{WARUNKOWA ZDOLNOŚĆ DO ZAPŁATY ZA KORZYŚCI ZEWNĘTRZNE GENEROWANE W WINNICACH O ZRÓWNOWAŻONEJ PRODUKCJI}

W badaniach mających na celu ocenę warunkowej zdolności do zapłaty za korzyści zewnętrzne generowane przez winnice w Polsce, w których stosuje się zrównoważoną uprawę winorośli, respondentów zapytano o ich gotowość do wyższej zapłaty za wino, które pochodziłoby $\mathrm{z}$ winnic:

- w których stosuje się uprawę ekologiczną;

- istotnie wzbogacających bioróżnorodność;

- istotnie wzbogacających atrakcyjność turystyczną regionu;

- istotnie wzbogacających atrakcyjność krajobrazu;

- w których sposób uprawy uwzględnia praktyki dostosowujące do zmian klimatu;

- w których używa się sprzętu i maszyn nieoddziałujących negatywnie na środowisko.

W badanej próbie (tabela 1.) nieznacznie wyższy udział miały kobiety $(54,9 \%)$ niż mężczyźni $(45,1 \%)$. Najliczniejszą kategorię respondentów według wieku stanowili ankietowani od 18. do 30. roku życia, których udział wyniósł 42,7\%. Udział respondentów z najstarszej grupy wiekowej (powyżej 60 lat) wyniósł 7,3\%. Prawie 60\% respondentów stanowiły osoby legitymujące się wyższym wykształceniem. Wysoki był również udział osób zamieszkujących w miastach $(66,5 \%)$. Wśród respondentów przeważały osoby aktywne zawodowo, których było prawie $60 \%$, deklarujące uzyskiwanie dochodów zbliżonych do średniej krajowej $(24,4 \%)$ lub powyżej średniej krajowej (70,1\%). Spośród badanych prawie $70 \%$ stanowiły osoby, które zadeklarowały, że piją wino co najmniej jeden raz w miesiącu lub częściej niż raz w miesiącu. Udział respondentów deklarujących picie wina rzadziej niż raz w miesiącu wyniósł $30 \%$.

W pierwszej kolejności zapytano respondentów o ich warunkową skłonność do zapłaty wyższej ceny za wino o określonych atrybutach, które powstały w trakcie uprawy winorośli i produkcji winogron, a które wpływają na generowanie korzyści zewnętrznych. 
Tabela 1. Cechy demograficzne badanych osób

\begin{tabular}{lccc}
\hline Czynnik & Skala & $\begin{array}{c}\text { Liczba } \\
\text { odpowiedzi }\end{array}$ & $\begin{array}{c}\text { Udział } \\
\text { odpowiedzi [\%] }\end{array}$ \\
\hline \multirow{2}{*}{ Wiek } & $18-30$ lat & 70 & 42,7 \\
& $31-60$ lat & 82 & 50,0 \\
Płeć & Powyżej 60 lat & 12 & 7,3 \\
\hline \multirow{3}{*}{ Wykształcenie } & Mężczyzna & 74 & 45,1 \\
& Kobieta & 90 & 54,9 \\
\hline \multirow{2}{*}{ Miejsce zamieszkania } & Zawodowe & 7 & 4,2 \\
& Średnie & 60 & 36,6 \\
& Wyższe & 97 & 59,2 \\
\hline \multirow{2}{*}{ Aktywność zawodowa } & Miasto & 109 & 66,5 \\
& Wieś & 55 & 33,5 \\
\hline \multirow{2}{*}{$\begin{array}{l}\text { Dochód rozporządzalny } \\
\text { na osobę w gospodarstwie }\end{array}$} & Niepracująca & 9 & 5,5 \\
domowym & Pracująca & 98 & 59,8 \\
& Zbludiująca & 48 & 29,3 \\
& Poniżej średniej krajowej & 9 & 5,5 \\
\hline
\end{tabular}

Źródło: badania własne.

Średnią ocenę czynników wpływających na skłonność do zapłacenia wyższej ceny za wino o określonych atrybutach przedstawiono w tabeli 2. Najwyżej ocenionym czynnikiem, który wpłynąłby na gotowość do zapłaty wyższej ceny, był certyfikat potwierdzający ekologiczny sposób uprawy winorośli i produkcji winogron. Cecha ta uzyskała ocenę 3,58 w pięciostopniowej skali (gdzie 5 oznacza maksimum). Drugi atrybut, który był istotny dla respondentów, to działania dostosowujące produkcję do zmian klimatycznych. Cecha ta uzyskała średnią ocenę 3,21. Wskazania te mogą sugerować, że decyzje o możliwości zapłacenia wyższej ceny za wino warunkowane były albo wysokim poziomem zaufania do środowiskowej wartości dodanej przejawiającej się posiadaniem certyfikatu potwierdzającego zgodność z ekologicznymi metodami produkcji [Ayyub i in. 2018], albo wynikały z czynników deklaratywnych, co do których konsumenci mają wysoki poziom zaufania warunkowany posiadaną wiedzą czy przekonaniami [Wells i in. 2010]. Atrybuty dotyczące korzyści zewnętrznych wynikających z atrakcyjności krajobrazu i atrakcyjności turystycznej regionu oceniono odpowiednio na 2,59 i 2,62. Średnie oceny, oscylujące wokół mediany dla badanej próby $(2,56)$, wskazują, że potencjalnie atrybuty te mogą odgrywać rolę podczas podejmowania decyzji o zapłacie wyższej ceny za wino [Lopes i in. 2014]. Ich wpływ musi być jednak wzmocniony szerszą wiedzą o konkretnym miejscu pochodzenia [Sadilek 2019]. Tym samym wyniki te mogą sugerować, że wiedza na temat danego miejsca warunkuje chęć do zapłaty za lokalne dobra publiczne. Najniższą średnią ocenę uzyskał czynnik związany z bioróżnorodnością $(2,17)$, może to być także związane $\mathrm{z}$ faktem niepełnej wiedzy i ograniczonej percepcji [Robertson i in. 2018, Gaeta, Corsinovi 2014]. 
Tabela 2. Ocena warunkowej skłonności do zapłaty wyższej ceny za wino o określonych atrybutach $(\mathrm{N}=174)$

\begin{tabular}{|c|c|c|c|c|c|c|}
\hline \multirow[b]{2}{*}{$\begin{array}{l}\text { Charakterystyka wariantu oceny warunkowej } \\
\text { skłonności do zapłaty wyższej ceny za wino }\end{array}$} & \multicolumn{5}{|c|}{$\begin{array}{c}\text { Udział osób wskazujących } \\
\text { skłonność do zapłaty za cenę } \\
\text { wina więcej niż [\%] }\end{array}$} & \multirow{2}{*}{$\begin{array}{l}\text { Średnia ocena } \\
\text { (skala } 1-\text { mini- } \\
\text { mum, } 5 \text { - mak- } \\
\quad \text { simum) }\end{array}$} \\
\hline & 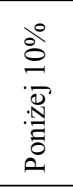 & $\begin{array}{l}\stackrel{0}{N} \\
\text { ஸे } \\
\end{array}$ & $\frac{\dot{0}}{\stackrel{0}{1}}$ & 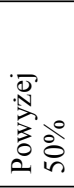 & 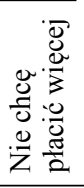 & \\
\hline $\begin{array}{l}\text { wino, którego sposób uprawy uwzględniałby } \\
\text { praktyki dostosowujące do zmian klimatu }\end{array}$ & 38,4 & 46,7 & 7,9 & 0,6 & 6,4 & 3,21 \\
\hline $\begin{array}{l}\text { wino, które pochodziłoby z winnic z ekologiczną } \\
\text { produkcją winorośli }\end{array}$ & 37,2 & 48,2 & 11,0 & 1,2 & 2,4 & 3,58 \\
\hline $\begin{array}{l}\text { wino, które pochodziłoby z winnic istotnie } \\
\text { wzbogacających bioróżnorodność }\end{array}$ & 54,9 & 33,5 & 1,2 & 0,6 & 9,1 & 2,17 \\
\hline $\begin{array}{l}\text { wino, które pochodziłoby z winnic istotnie } \\
\text { wzbogacających atrakcyjność turystyczną regionu }\end{array}$ & 50,3 & 33,5 & 4,5 & 1,8 & 9,8 & 2,62 \\
\hline $\begin{array}{l}\text { wino, które pochodziłoby z winnic istotnie } \\
\text { wzbogacających atrakcyjność krajobrazu }\end{array}$ & 55,5 & 31,3 & 1,9 & 1,8 & 9,5 & 2,59 \\
\hline $\begin{array}{l}\text { wino, które pochodziłoby } \mathrm{z} \text { winnic używających } \\
\text { sprzętu i maszyn nieoddziałujących negatywnie } \\
\text { na środowisko }\end{array}$ & 53,0 & 37,2 & 3,6 & 1,3 & 4,9 & 2,80 \\
\hline
\end{tabular}

Źródło: badania własne.

W dalszej części badania zapytano respondentów, o ile procent więcej są warunkowo skłonni zapłacić za wino o określonych atrybutach, które powstały w trakcie uprawy winorośli i produkcji winogron, a które wpływają na generowanie korzyści zewnętrznych. $\mathrm{W}$ tabeli 2 . zaprezentowano przedziały zwiększenia ceny, w ramach których udzielano odpowiedzi. Wskazania respondentów potwierdzają istotność czynników zaufania i wiedzy w podejmowaniu decyzji o zapłacie wyższej ceny. Gotowość do zapłaty ceny w dominującym przedziale $10-20 \% \mathrm{w}$ odniesieniu do ceny wina $\mathrm{z}$ upraw ekologicznych zadeklarowało prawie $49 \%$ badanych, zaś z upraw dostosowanych do zmian klimatu 46,7\%, przy czym za wina ekologiczne aż $11 \%$ badanych skłonnych było zapłacić wyższą cenę w przedziale 21-50\%. Warunkowa gotowość do zapłaty za wino cechujące się pozostałymi badanymi atrybutami dominowała w przedziale, gdzie wzrost ceny nie przekroczyłby $10 \%$. Gotowość do zapłaty za te cechy deklarowała ponad połowa badanych. Jednocześnie prawie co 10 badany wskazał, że nie chce płacić więcej za wina, które pochodzą z upraw wzbogacających bioróżnorodność, atrakcyjność krajobrazu czy atrakcyjność turystyczną.

\section{PODSUMOWANIE}

Na podstawie przeprowadzonych badań można stwierdzić, że uprawa winorośli i produkcja winogron z przeznaczeniem na wino odbywająca się w sposób zrównoważony cechują się występowaniem korzyści zewnętrznych. Korzyści te wynikają z lokalnego 
charakteru dóbr publicznych, do których można zaliczyć przede wszystkim dany ekosystem określany jako terroir i powiązane $\mathrm{z}$ nim sieciowo elementy takie jak bioróżnorodność czy krajobraz. Oddziałują one w sposób synergiczny na inne korzyści zewnętrzne o charakterze społecznym, takie jak atrakcyjność turystyczna czy dziedzictwo kulturowe. Występowanie określonych korzyści zewnętrznych w uprawach winogron warunkowane jest stopniem zrównoważenia ich produkcji przejawiającym się w stosowaniu określonych praktyk produkcyjnych, często potwierdzanych certyfikatami jakości.

Mając na uwadze fakt, że uprawa winorośli z przeznaczeniem na wino i produkcja wina $\mathrm{w}$ Polsce dynamicznie wzrastają, a zmiany klimatu będą wpływały na dalsze potencjalne możliwości rozwoju tego sektora, ważne jest wskazanie jego kierunku. Badani konsumenci wskazali, że ważne są dla nich takie atrybuty wina jak ekologiczny sposób produkcji czy praktyki odpowiadające na zmiany klimatu. W większości są oni gotowi zapłacić za nie więcej niż za cechy związane z innymi korzyściami zewnętrznymi (np. bioróżnorodność, krajobraz).

Wnioski te pozwalają na formułowanie rekomendacji co do opcji strategicznych rozwoju polskiego winiarstwa w warunkach zmian klimatu. Producenci wina w Polsce powinny zainteresować się przestawieniem produkcji na zgodność z wymaganiami rolnictwa ekologicznego. Trend taki obserwowany jest w innych krajach, nie tylko Starego Kontynentu, ale także Nowego Świata, tak o bardziej rozwiniętej jak i rozwijającej się produkcji [por. Willer, Lernoud 2017], pozwoli to na skorzystanie z efektu sieciowego i generowanie korzyści zewnętrznych o charakterze synergicznym, które mogą przełożyć się na chęć konsumentów do zapłaty wyższej ceny.

\section{LITERATURA}

Ayyub Samia, Wang Xuhui, Asif Muhammad, Ayyub Rana 2018: Antecedents of Trust in Organic Foods: The Mediating Role of Food Related Personality Traits. Sustainability 10(10), s. 1-17.

Belletti Giovanni, Marescotti Andrea, Touzard Jean-Marc 2015: Geographical Indications, Public Goods, and Sustainable Development: The Roles of Actors'Strategies and Public Policies. World Development 95, s. 45-57.

Boatto Vasco, Galletto Luigi, Barisann Luigino, Bianchin Federica 2013: The development of wine tourism in the Conegliano Valdobbiadene area. „Wine Economics and Policy” 2, s.93-101.

Brelik Agnieszka 2011: Dobra publiczne a wielofunkcyjny rozwój rolnictwa. „Zeszyty Naukowe Ostrołęckiego Towarzystwa Naukowego" nr 25, s. 225-230

Cooper Tamasin, Hart Kaley, Baldock David 2009: Provision of public goods through agriculture in European Union, IEEP, London.

Czyżewski Andrzej, Kułyk Piotr 2013: Kwestia rolna w teorii wyboru publicznego, „,Roczniki Naukowe Ekonomii Rolnictwa i Rozwoju Obszarów Wiejskich”, 100 (3), s. 7-18.

Dodds Rachel, Graci Sonya, Ko Soyoung, Walker Lindsay 2013: What drives environmental sustainability in the New Zealand wine industry? „Int. J. Wine Bus. Res.” 25, s. 64-184.

Gaeta Davide, Corsinovi Paola 2014: Economics, governance, and politics in the wine market European Union Developments. Palgrave Macmillan, London.

Gibbons María Amelia, Maffioli Alessandro, Rossi Martín Antonio 2016: Money for Wine? Complementarities in the Provision of Private and Public Goods to Wine Producers, IDB Working Paper Series, No. IDB-WP-689, Inter-American Development Bank (IDB), Washington, DC. 
Gołębiewska Barbara, Pajewski Tomasz 2018: Positive and negative externalities of management illustrated by the case of agricultural production. „Journal of Agribusiness and Rural Development", 2(48), s.113-120.

Harasim Adam 2015: Zagadnienie dóbr publicznych zwiazanych z rolnictwem i obszarami wiejskimi. Studia i raporty IUNG-PIB, 43(17), s. 117-137.

Klohr Bastian, Fleuchaus Ruth, Theuvsen Ludvig 2014: Who is buying sustainable wine? A lifestyle segmentation of German wine consumers. In Proceedings of the 8th International Conference of the Academy of Wine Business Research, Geisenheim, Germany, 28-30 June 2014.

KOWR (Krajowy Ośrodek Wsparcia Rolnictwa) 2019: Rynek wina w liczbach. Warszawa.

KPMG 2014. Rynek napojów alkoholowych w Polsce. KPMG, Warszawa.

Kunicka-Styczyńska Alina, Czyżowska Agata, Rajkowska Katarzyna, Wilkowska Agnieszka, Dziugan Piotr 2016: The trends and prospects of winemaking in Poland [w] Antonio Morata and Iris Loira (eds.) Grape and Wine Biotechnology, In.Tech. Publ., 401-414.

Lee Hannah, Roehrdanz Patrick R., Ikegami Makihiko, Shepard Anderson V., Shaw M. Rebecca, Tabor Gary, Zhi Lu, Marquet Pablo A., Hijmans Robert J., 2013: Climate change, wine, and conservation. Proceedings of the National Academy of Sciences Apr. 2013, 110 (17), s.6907-6912.

Lisek Jerzy 2008: Climatic factors affecting development and yielding of grapevine in Central Poland. ,Journal of Fruit and Ornamental Plant Research” Vol. 16, 2008, s. 285-293.

Lopes Pedro, Sagala Richard, Dood Thomas 2014: Extrinsic wine attributes importance on Canadian consumers purchase decisions for environmentally sustainable wines [w] Proceedings of the 8th International Conference of the Academy of Wine Business Research, Geisenheim, Germany, 28-30 June 2014.

Lourenco-Gomes Lina, Rebelo Joao 2006: Cultural heritage policy. The Alto Douro wine region - World Herita-ge Site. Is there an argument for reinforcing the role of the state? PASOS: Revista de Turismo y Patrimonio Cultural. 4.

Maciejczak Mariusz 2017: Innovations in viticultural production in Poland under climate change conditions. „Roczniki SERiA”, t. XIX, z. 2, s. 151-157.

Maciejczak Mariusz, Grzelak Paweł 2013: Metody wyceny dóbr nierynkowych na obszarach wiejskich. „Zagadnienia Ekonomiki Rolnej”, 3, s.143-150.

Maciejczak Mariusz 2009: Rolnictwo i obszary wiejskie źródtem dóbr publicznych - przeglad literatury, „Zeszyty Naukowe SGGW, Ekonomika i Organizacja Gospodarki Żywnościowej”, 75, s. 121-128.

Maciejczak Mariusz, Mikiciuk Jakub 2019: Climate change impact on viticulture in Poland, „International Journal of Climate Change Strategies and Management”, 11 (2), s. 254-264.

Małażewska Sylwia 2015: Środowiskowe dobra publiczne $w$ rolnictwie $i$ na obszarach wiejskich. „Ekonomia i Środowisko” 1 (52), s. 142-147.

Marshall R. Scott, Akoorie Michčle E.M., Hamann Ralph, Sinha Paresha 2010: Environmental practices in the wine industry: An empirical application of the theory of reasoned action and stakeholder theory in the United States and New Zealand. J. World Bus. 45, s. 405-414.

Miłaszewski Rafał 2009: Metody określania kosztów środowiskowych i zasobowych spowodowanych użytkowaniem wód, Środkowo-Pomorskie Towarzystwo Naukowe Ochrony Środowiska, Tom 11. Politechnika Białostocka.

Murray Silverman, Marshall R. Scott, Cordano Mark 2005: The Greening of the California Wine Industry: Implications for Regulators and Industry Associations. ,Journal of Wine Research”, Vol. 16, No. 2, s. 151-169.

Osadebamwen Ogbeide 2015: Consumer Willingness to Pay a Premium for Organic Wine: Discriminant analysis. Mayfair Journal of Agribusiness Management, 1, s. 24-42. 
Olewnicki Dawid 2018: Uprawa winorośli w Polsce w świetle danych statystycznych. „Roczniki Naukowe SERiA", 20(5), s. 139-145

Pajewski Tomasz, Gołębiewska Barbara 2018: Rolnictwo a środowisko. Efekty zewnętrzne w systemach produkcji rolnej. Wyd. SGGW.

Penco Pierpaolo 2016: Sustainability, environment, innovation and marketing: the wine industry challenge. MIB Trieste School of Management.

Pigou Arthur 1932: The Economics of Welfare, Macmillan, London.

Pomarici Eugenio, Vecchio Riccardo, Mariani Angela 2015: Wineries'Perception of Sustainability Costs and Benefits: An Exploratory Study in California. Sustainability 7, s. 16164-16174.

Pretty Jules, Craig Brett, Gee David, Hine Rachel, Mason Chris, Morison James, Rayment Matthew, Van Der Bijl Gert, Dobbs Thomas 2001: Policy Challenges and Priorities for Internalizing the Externalities of Modern Agriculture, „Journal of Environmental Planning and Management", 44, s. 2, 263-283.

Robertson Jeandri, Ferreira Caitlin, Botha Elsamari 2018: The influence of product knowledge on the relative importance of extrinsic product attributes of wine, „Journal of Wine Research”, 29 , s. 3, 159-176.

Robinson Jancis (ed), 2006: The Oxford Companion to Wine. Third Edition Oxford University Press, s. 152-153.

Sadilek Tomas, 2019: Perception of Food Quality by Consumers: Literature Review. European Research Studies Journal 22(1), s. 52-62.

Sadowski Maciej (red.) 2014: Raport końcowy projektu Klimada „Opracowanie i wdrożenie Strategicznego Planu Adaptacji dla sektorów i obszarów wrażliwych na zmiany klimatu”. Instytut Ochrony Środowiska-PIB, Warszawa, s. 295-308.

Santini Cristina, Cavicchi Alessio, Casini Leonardo 2015: Sustainability in the Wine Industry: Key Questions and Research Trends. Environmentally Sustainable Viticulture: Practices and Practicality. 3-23

Sellers-Rubio Ricardo, Nicolau-Gonzalbez Juan Luis 2016: Estimating the willingness to pay for a sustainable wine using a Heckit model. „Wine Economics and Policy”, 5 (2), s. 96-104.

Stefanucci Stefano, Graça António, Novello Vittorino, Belda Ignacio, Carlos Cristina, Gautier Jacques, 2018: Functional biodiversity in the vineyard. OIV - International Organisation of Vine and Wine, Paris.

Stiglitz Joseph E. 2004: Ekonomia sektora publicznego, Wydawnictwo Naukowe PWN, Warszawa, s. $254-291$.

Tee Edward., Boland Anne Mare, Medhurst A. 2007: Voluntary adoption of Environmental Management Systems in the Australian wine and grape industry depends on understanding stakeholder objectives and drivers. Anim. Prod. Sci. 47, s. 273-283.

Vecchio Riccardo 2013: Determinants of willingness-to-pay for sustainable wine: Evidence from experimental auctions. Wine Econ. Policy 2, s. 85-92.

Wells Victoria K., Ponting Cerys, Peattie Ken 2010: Behaviour and Climate Change: Consumer Perceptions of Responsibility. „Journal of Marketing Management”, 27, s. 808-833.

Willer Helga, Lernoud Julia 2017: Organic Viticulture Worldwide 2015, Research Institute of Organic Agriculture (FiBL), Frick, Switzerland, April 2017.

Winkler Klara J., Kimberly A. Nicholas, 2016: More than wine: Cultural ecosystem services in vineyard. „Ecological Economics”, 124, s. 86-98.

Zhenmin Liu, Espinosa Patricia, 2019: Tackling climate change to accelerate sustainable development. Nature Climate Change, 9, s. 494-496. 


\title{
Mariusz Maciejczak
}

\section{THE EXTERNAL BENEFITS OF SUSTAINABLE VINEYARDS IN POLAND UNDER THE CONDITIONS OF CLIMATE CHANGE}

\begin{abstract}
Summary
The research aimed to determine the types of external benefits associated with running the vineyard in accordance to with the principles of sustainable production, and then, based on conclusions from the assessment of the development of vineyards growing in Poland under climate change conditions, to examine consumer opinions on their willingness to pay for wine originating from crops that generate positive externalities. It was found that the cultivation of grapes in a sustainable manner is characterized by the existence of external benefits. These benefits result from the local character of public goods, which include primarily the ecosystem described as terroir and related elements such as biodiversity and landscape. They interact in a synergistic way to other external social benefits, such as tourist attractiveness or cultural heritage. It has been shown that viticulture for wine and wine production in Poland is growing rapidly, and climate change will affect further potential development opportunities for this sector. The surveyed consumers pointed out that the wine attributes such as the organic way of production or practices responding to climate change are important for them. For the most part, they are willing to pay for it more than for features related to other external benefits, i.e. biodiversity or landscape. It is argued, that orientation of Polish vineyards to produce in a way that generates external benefits, ie. organically, will allow to take advantage of the network effect which may translate into the desire of consumers to pay a higher price for wine.
\end{abstract}

Adres do korespondencji: Mariusz Maciejczak (orcid.org/0000-0002-0630-5628) Katedra Ekonomiki i Organizacji Przedsiębiorstw Wydział Nauk Ekonomicznych

Szkoła Główna Gospodarstwa Wiejskiego w Warszawie ul. Nowoursynowska 166 02-787 Warszawa Tel.: 22 / 5934235 e-mail: mariusz_maciejczak@sggw.pl 